\title{
PERENCANAAN REST AREA DENGAN KONSEP MICHI-NO EKI DI JALUR NON-TOL (Studi Kasus: Kabupaten Barru, Provinsi Sulawesi Selatan)
}

\author{
Muhammad Yusri Lukman ${ }^{1}$, Muhammad Zaki ${ }^{2}$, Ermywati HR $^{3}$ \\ ${ }^{1,2,3}$ Prodi Arsitektur, Fakultas Teknik, Universitas Muslim Indonesia
}

\begin{abstract}
Abstrak
Penelitian ini adalah dasar acuan analisis dan standar yang akan digunakan dalam pekerjaan pembangunan tempat peristirahatan pengguna jalan raya. Penelitian ini bersifat deskriptif, Penelitian dilakukan di kecamatan Soppeng Riaja desa Lawallu Kabupaten Barru Provinsi Sulawesi selatan. Pengumpulan data dilakukan melalui observasi dan wawancara. Data kendaraan yang dibutuhkan disamping volume arus lalulintas adalah jenis kendaraan dan arah pergerakannya. Metode analisis yang digunakan adalah metode hubungan sebab akibat. Suatu fenomena akan dianalisis tentang akibat yang terjadi dari suatu perlakuan. Hasil kajian yang memberi dampak positif akan dikembangkan sementara efek kajian yang bernilai negatif akan ditelusuri secara mendalam untuk mendapatkan hasil keputusan optimal. Metode dan standar ini meliputi dasar hukum perbandingan dan ketentuan dasar pergerakan kendaraan. Standar yang dimaksudkan dalam pembahasan ini adalah persyaratan umum yang harus dipenuhi untuk memberi pelayanan minimum kepada kendaraan dan pengguna rest area. Michi no Eki adalah sebuah konsep rest area yang menyediakan tempat beristirahat nyaman dan layanan berkualitas lainnya bagi pengguna jalan, dengan melibatkan peran serta masyarakat lokal.
\end{abstract}

Kata kunci: Rest Area, Michi-No Eki

\section{PENDAhuluan}

Provinsi Sulawesi Selatan meraih predikat Daerah dengan tingkat pertumbuhan ekonomi tertinggi di Indonesia. Prestasi ini semakin memacu pemerintah untuk membantu daerah yang terdapat di Sulawesi Selatan saling meningkatkan potensinya, baik dari segi pariwisata, Sumber Daya Alam dll. Jumlah kendaraan bermotor yang ada di Sulawesi Selatan semakin meningkat. Untuk menjangkau setiap daerah seringkali masyarakat menempuh jalur darat yang menjadi salah satu pilihan pengendara kendaraan umum.

Berbagai perkembangan aspek kehidupan yang terus meningkat di Propinsi Sulawesi Selatan, menciptakan suatu kondisi yang menuntut adanya peningkatan kesejahteraan masyarakat di sekitarnya. Perkembangan ekonomi yang terjadi saat ini merupakan salah satu aspek yang paling dirasakan di samping berbagai aspek yang lain. Berkaitan dengan Peningkatan pelayanan jasa distribusi yang merupakan penunjang terhadap pertumbuhan ekonomi tersebut, maka dikembangkanlah suatu fasilitas Jalan Lintas Propinsi. Penyelenggaraan Jalan Lintas Propinsi dimaksudkan untuk mewujudkan pemerataan pembangunan dan hasilhasilnya, serta keseimbangan dalam pengembangan wilayah yang dapat dicapai dengan membina jaringan jalan. Jalan Lintas Propinsi di Sulawesi Selatan dikenal senagai Jalan Poros Sulawesi.

Jalur transportasi Poros Sulawesi merupakan salah satu bukti nyata terhadap perkembangan yang terjadi di Sulawesi Selatan. Meningkatnya volume lalu lintas pada jalur ini menciptakan suatu kebutuhan terhadap Peningkatan kualitas Jalan Poros Sulawesi Selatan. Pada akhir April 2008, Revitalisasi jalan poros yang menghubungkan kota di Sulawesi Selatan dimulai dari Makassar - Parepare. Jalan relatif lurus dan lebar dengan kualitas yang baik.

Salah satu keluhan yang sering dirasakan oleh pemudik adalah lebih mudah ngantuk ketika melewati jalan lurus. Hal ini ternyata ada penjelasan medisnya. Matthews $G$ dan Desmond A dalam artikel ilmiah yang dilansir The Quarterly Journal of Experimental Psychology pada 2002 lalu mengatakan bahwa melalui studi simulator, memang ditemukan kalau terjadi penurunan kinerja yang signifikan ketika berkendara di ruas jalan lurus. Hal yang sama dikatakan oleh Centre for Accident Research \& Road Safety--Queensland (CARRS-Q). Mereka menyebut kalau "jalanan lurus yang panjang berbahaya karena dapat membuat ngantuk". Lantas, mengapa hal ini bisa terjadi, Pierre Thiffault dan Jacques Bergeron di jurnal Accident Analysis and Prevention pada 2001 mengatakan bahwa hal tersebut sangat berkaitan dengan situasi monoton yang dialami tubuh. Ketika tubuh monoton, kewaspadaan berkurang.Untuk mengakomodasi kelelahan di Jalan Poros Provinsi Sulawesi Selatan perlu difasilitasi dengan fasilitas transportasi umum seperti Rest Area.

Rest area adalah salah satu fasilitas prasarana transportasi umum yang merupakan tempat / lokasi peristirahatan bagi pengemudi, penumpang, maupun 
kendaraannya (baik sepeda motor maupun mobil ) yang dipadukan dengan fasilitas parkir kendaraan (sepeda motor atau mobil). Tujuan pengadaan fasilitas ini adalah agar pengemudi dan pengguna jalan lainnya dapat beristirahat untuk sementara. Kegiatan istirahat selama perjalanan bukan saja bertujuan untuk memulihkan tanaga bagi pengguna jalan tetapi juga untuk menghindari terjadinya kecelakaan.

Rest area pada dasarnya difasilitasi dengan toilet, tempat ibadah, informasi lalu lintas hingga SPBU dan kuliner, yang terletak pada daerah yang nyaman dan berada di sisi ruas jalan raya sehingga lebih muda di akses. Undang-undang 22 tahun 2009 pada pasal 90 ayat 3 menyebutkan "Pengemudi Kendaraan Bermotor Umum setelah mengemudikan Selama 4 (empat) jam berturut-turut wajib beristirahat paling singkat setengah jam. Dengan menelaah undang undang dan melihat kondisi geografis Provinsi Sulawesi Selatan yang dilewati jalan utama sudah semestinya difasilitasi Rest Area untuk memberikan kenyamanan pengendara dan pengguna jalan lainnya. Fasilitas ini akan menjadi titik istirahat bagi pengemudi dan penumpang kendaraan umum.

Michi no Eki adalah sebuah konsep rest area yang menyediakan tempat beristirahat nyaman dan layanan berkualitas lainnya bagi pengguna jalan, dengan melibatkan peran serta masyarakat lokal. Konsep ini berangkat dari pemikiran Semakin meningkatnya jumlah pengendara yang menempuh perjalanan jauh melalui jalan darat membuat pemerintah Jepang memandang perlu untuk menyediakan rest area sebagai tempat para pengendara untuk beristirahat. Michi-no Eki bertujuan untuk memberikan kontribusi terhadap keselamatan dan kenyamanan di jalan, di lengkapi dengan media untuk mempromosikan produkproduk dan aktivitas lokal. Prinsip-prinsip dari Michi no Eki adalah menyediakan fasilitas untuk beristirahat

Tujuan yang ingin dicapai dalam penelitian ini adalah dasar acuan analisis dan standar yang akan digunakan dalam pekerjaan pembangunan tempat peristirahatan pengguna jalan raya

\section{ISI PENELITIAN}

\subsection{Lokasi dan Rancangan Penelitian}

Penelitian ini dilakukan di kecamatan Soppeng Riaja Desa Lawallu Kabupaten Barru Provinsi Sulawesi selatan. Analisis penentuan lokasi merupakan langkah selanjutnya setelah menentukan kelayakan pembangunan. Penetuan lokasi merupakan kegiatan yang berada dalam tingkat kesulitan. Hal ini disebabkan oleh kesulitan mendapatkan lahan teruatama lahan yang berada ditepi jalan. Lahan yang berada ditepi jalan memiliki nilai ekonomi yang cukup tinggi. Akibat peningkatan nilai ekonomi tanah tersebut mengakibatkan banyak lahan yang beralih fungsi.
Lahan yang tadinya berupa lahan pertanian dan tambak yang berada di tepi jalan berubah fungsi menjadi lahan permikiman yang dibangun menjadi perumahan atau perkantoran.

Lahan lokasi alternative ini merupakan lahan tambak yang telah tertekan oleh perkembangan kebutuhan permukiman. Berdasarkan pengamatan dilapangan dan keterangan warga disebutkan bahwa lahan tambak yang berada di tepi jalan telah mengalami banyak penurunan produktifitas dan tuntutan pengelolaan yang ekstra. Tapak lokasi pembangunan rest area lokasi desa Lawallu berada di sebelah utara kota Barru dengan jarak $22 \mathrm{Km}$. Luas lahan yang tersedia sekitar 4,59 Ha. Pengembangan kawasan untuk pertambahan kebutuhan di masa datang terbuka dan berpeluang besar di kawasan ini. View menarik yang ditawarkan di tapak ini dengan sajian pandangan air berlatar belakang hutan mangrove disebelah barat. Sajian sebelah timur menyajikan pandangan jalur rel kereta api.

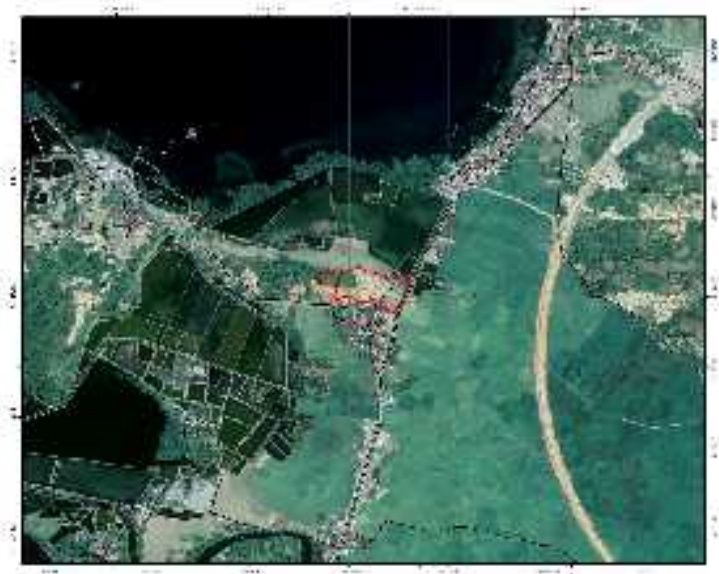

Gambar 1. Lokasi Desa Lawallu

Jenis penelitian yang digunakan adalah penelitian deskriptif yaitu suatu penelitian yang mendeskripsikan atau menggambarkan kondisi ketersediaan prasarana umum. Metode dan standar ini meliputi dasar hukum perbandingan dan ketentuan dasar pergerakan kendaraan. Standar yang dimaksudkan dalam pembahasan ini adalah persyaratan umum yang harus dipenuhi untuk memberi pelayanan minimum kepada kendaraan dan pengguna rest area

\subsection{Metode Pengumpulan Data}

Metode pengambilan data dilakukan sesuai kebutuhan data. Data sirkulasi kendaraan yang melintasi jalur utama di Kabupaten Barru akan dilakukan dengan cara pengamatan dan pencataan langsung. Penyajian data volume arus lalulintas di Kabupaten Barru sangat berperan dalam memberikan alas an kalayakan pembangunan rest area. Data kendaraan yang dibutuhkan disamping volume arus lalulintas adalah jenis kendaraan dan arah pergerakannya. Jenis kendaraan meliputi 
klasifikasi kendaraan yang berlalu lintas yang terdiri dari kendaraan roda 2, roda empat, bus, truk trailer, dan mobil box. Arah arus kendaraan yang peru diperhatikan adalah velume pergerakan dari arah utara ke selatan dan sebaliknya.

Kondisi persinggahan kendaraan yang dimaksudkan adalah kegiatan pengamatan terhadap kendaraan yang berhenti dengan tujuan tertentu di salah satu titik kegiatan persinggahan. Pengambilan data pemberhentian kendaraan dilakuan dengan cara random. Kondisi ketersediaan lahan dilakukan pengamatan langsung dilapangan. Alternative yang berpeluang diberi pertimbangan untuk dikoordinasikan dengan pemerintah setempat. Hasil anallisis akan digunakan sebagai dasar oleh pemerintah untuk melakukan tindakan lanjutan sesuai perkembangan kebijakan yang berjalan. Aspek penunjang pembangunan berkaitan dengan fasilitas pendukung yang dapat membantu kehadiran rest area. pendataan tentang aspek penunjang ini dilakukan dengan cara pengamatan langsung.

\subsection{Analisis Data}

Metode analisis yang digunakan adalah metode hubungan sebab akibat. Suatu fenomena akan dianalisis tentang akibat yang terjadi dari suatu perlakuan. Hasil kajian yang memberi dampak positif akan dikembangkan sementara efek kajian yang bernilai negative akan ditelusuri secara mendalam untuk mendapatkan hasil keputusan optimal.

\section{HASIL \& PEMBAHASAN}

\subsection{Hasil Penelitian}

Pembahasannya akan dilakukan dengan cara mengemukakan tanggapan yang diperoleh dari ketentuan Kerangka Acuan Kerja. Ketentuan ini selanjutnya disusun menjadi pemaparan potensi wilayah Sulawesi Selatan dan Kabupaten Barru. Pembahasan selanjutnya adalah mengemukakan fenomena pergerakan kendaraan di kawasan ini dan keterkaitannya dengan wilayah lain. Atas dasar kajian transportasi dan potensi kawasan disusun suatu kesimpulan tentang pembangunan fungsi rest area.

\section{a. Strategi Penyusunan Rest Area}

Tempat persinggahan kendaraan atau dikenal secara lebih luas sebagai rest area adalah tempat beristirahat sejenak untuk melepaskan kelelahan, kejenuhan, ataupun ke toilet selama dalam perjalanan jarak jauh. Peraturan perundangan mengenai Lalu Lintas dan Angkutan Jalan telah menerbitkan ketentuan yang menyebutkan bahwa setiap mengemudikan kendaraan selama 4 jam harus istirahat selama sekurang-kurangnya setengah jam, untuk melepaskan kelelahan, tidur sejenak ataupun untuk minum kopi, makan ataupun ke kamar kecil/toilet. Waktu kerja bagi Pengemudi Kendaraan Bermotor Umum paling lama 8 (delapan) jam sehari, sehingga dibutuhkan tempat istirahat juga digunakan untuk tempat pergantian pengemudi.

Munculnya tempat peristirahatan kendaraan di jalan arteri yang tidak terkendali secara baik dapat menimbulkan gangguan lalulintas di lintasannya. Penempatan persinggahan yang dikelola secara spontan oleh masyarakat penempatannya sangat tergantung kepada pemilik lahan atau modal dan berkembang secara tidak terencana, sehingga sering mengakibatkan kemacetan. Hal ini terjadi karena akses masuk tidak direncanakan dengan baik. Pertimbangan yang matang perlu menjadi perhatian dalam perencanaan tempat istirahat untuk menekan kecelakaan lalu lintas.

Tabel 1. Jumlah kendaraaan dan jenisnya di Provinsi Sulawesi Selatan

Sumber : Ditlantas Polda Sulawesi Selatan dalam BPS Sulawesi Selatan up date 6 oktober 2015

\begin{tabular}{|c|c|c|c|c|c|c|c|}
\hline No & \multicolumn{2}{|l|}{ Kabupaten } & \begin{tabular}{c|} 
Mobil \\
Penumpang \\
\end{tabular} & \begin{tabular}{|l|}
$\begin{array}{l}\text { Kendaraan } \\
\text { Khusus }\end{array}$ \\
\end{tabular} & Bus & Truk & $\begin{array}{l}\text { Sepeda } \\
\text { Motor }\end{array}$ \\
\hline 1 & \multicolumn{2}{|c|}{ Kepulauan Selayar } & 387 & 27 & 67 & 250 & 10.531 \\
\hline 2 & \multicolumn{2}{|l|}{ Bulukumba } & 4.542 & 29 & 339 & 3.275 & 68.981 \\
\hline 3 & \multicolumn{2}{|l|}{ Bantaeng } & 1.245 & 33 & 103 & 1.222 & 20.68 \\
\hline 4 & \multicolumn{2}{|l|}{ Jeneponto } & 2.146 & 33 & 207 & 1.923 & 26.012 \\
\hline 5 & \multicolumn{2}{|l|}{ Takalar } & 2.347 & 24 & 70 & 1.711 & 60.228 \\
\hline 6 & \multicolumn{2}{|l|}{ Gowa } & 12.35 & 61 & 185 & 6.394 & 177.861 \\
\hline 7 & \multicolumn{2}{|l|}{ Sinjai } & 1.491 & 33 & 140 & 1.151 & 34.336 \\
\hline 8 & \multicolumn{2}{|l|}{ Maros } & 4.625 & 33 & 46 & 2.142 & 37.2 \\
\hline 9 & \multicolumn{2}{|l|}{ Pangkep } & 5.999 & 40 & 57 & 3.439 & 66.772 \\
\hline 10 & \multicolumn{2}{|l|}{ Barru } & 1.849 & 8 & 5 & 1.24 & 28.039 \\
\hline 11 & \multicolumn{2}{|l|}{ Bone } & 3.535 & 68 & 3.687 & 5.805 & 121.571 \\
\hline 12 & \multicolumn{2}{|l|}{ Soppeng } & 2.021 & 14 & 1.278 & 3.409 & 42.12 \\
\hline 13 & \multicolumn{2}{|l|}{ Wajo } & 6.266 & 32 & 71 & 4.412 & 96.744 \\
\hline 14 & \multicolumn{2}{|l|}{ Sidrap } & 4.069 & 32 & 165 & 2.683 & 59.035 \\
\hline 15 & \multicolumn{2}{|l|}{ Pinrang } & 6.446 & 32 & 29 & 4.142 & 122.484 \\
\hline 16 & \multicolumn{2}{|l|}{ Enrekang } & 948 & 31 & 40 & 918 & 26.751 \\
\hline 17 & \multicolumn{2}{|l|}{ Luwu } & 2.731 & 31 & 34 & 1.541 & 69.682 \\
\hline 18 & \multicolumn{2}{|l|}{ Tana Toraja } & 1.877 & 30 & 78 & 2.11 & 42.786 \\
\hline 19 & \multicolumn{2}{|c|}{ Luwu Utara } & 1.409 & 30 & 14 & 1.265 & 51.004 \\
\hline 20 & \multicolumn{2}{|l|}{ Luwu Timur } & 3.54 & 27 & 145 & 2.834 & 60.149 \\
\hline 21 & \multicolumn{2}{|l|}{ Toraja Utara } & - & - & - & - & \\
\hline 22 & \multicolumn{2}{|l|}{ Makassar } & 151.328 & 374 & 16.981 & 57.601 & 926.097 \\
\hline 23 & \multicolumn{2}{|l|}{ Pare Pare } & 10.918 & 17 & 44 & 6.283 & 75.319 \\
\hline 24 & \multicolumn{2}{|l|}{ Palopo } & 4.183 & 45 & 88 & 2.226 & 70.215 \\
\hline \multirow{5}{*}{\multicolumn{2}{|c|}{ Sulawesi Selatan }} & 2013 & 236.252 & 1.027 & 23.873 & 117.976 & 2.294 .597 \\
\hline & & \begin{tabular}{|l|}
2012 \\
\end{tabular} & 209.922 & 1.11 & 24.974 & 110.027 & 2.247 .380 \\
\hline & & \begin{tabular}{|l|}
2011 \\
\end{tabular} & 188.715 & 1.086 & 25.201 & 100.009 & 2.057 .345 \\
\hline & & \begin{tabular}{|l|}
2010 \\
\end{tabular} & 161.257 & 938 & 23.855 & 86.055 & 1.655 .489 \\
\hline & & \begin{tabular}{|l|}
2009 \\
\end{tabular} & 136.352 & 938 & 35.822 & 80.516 & 1.538 .733 \\
\hline
\end{tabular}

Jumlah kendaraan yang berakibat kepada dinamika pergerakan masyarakat menuntut adanya sarana dan prasarana. Salah satu tuntutan yang berhubungan langsung dengan pergerakan penduduk beserta alat transportasinya adalah fasilitas infra struktur jalan. Tabel 2 berikut menggambarkan panjang jalan di Provinsi Sulawesi Selatan menurut lokasinya per Kabupaten.

Tabel 2. Panjang Jalan Di Sulawesi Selatan

Sumber: BPS Provinsi Sulwesi Selatan 2013

\begin{tabular}{|r|l|r|r|r|r|}
\hline \multirow{2}{*}{ No } & \multirow{2}{*}{ Status Jalan } & \multicolumn{4}{|c|}{ Panjang Jalan ( KM) } \\
\cline { 3 - 6 } & & \multicolumn{1}{c|}{2009} & \multicolumn{1}{c|}{2010} & \multicolumn{1}{c|}{2011} & \multicolumn{1}{c|}{2012} \\
\hline 1 & Jalan Nasional & 1,723 & 1,723 & 1,723 & 1,723 \\
\hline 2 & Jalan Provinsi & 1,260 & 1,260 & 1,260 & 1,260 \\
\hline 3 & $J a l a n$ Kabupaten / Kota & 29,698 & 29,570 & 29,570 & 29,710 \\
\hline \multicolumn{2}{|c|}{ Total Panjang Jalan } & 32,681 & 32,553 & 32,553 & 32,693 \\
\hline
\end{tabular}

Data diatas menggambarkan adanya indikasi yang tidak berimbang antara peningkatan jumlah kendaraan dalam tabel 1 dengan jumlah panjang 
jalan dalam tabel 2. Peningkatan jumlah kendaraan nampaknya tidak diikuti oleh peningkatan panjang jalan. Kondisi seperti ini tentunya akan menimbulkan masalah dimasa datang. Permasalahan yang diketahui sebelum terjadi adalah kegiatan cerdas. Sehubungan dengan hal tersebut kehadiran tempat peristirahatan nampaknya akan menjadi salah satu penyelesaian masalah dari sekian banyak masalah dalam system transportasi.

\section{b. Strategi Penyusunan Rest Area}

Kabupaten Barru merupakan salah satu daerah yang mendapatkan perhatian khusus dalam pengembangan pembangunan di Provinsi Sulawesi Selatan. Rencana pengembangan pembangunan ini dapat dilihat pada saat ini dengan kegiatan yang paling menonjol berupa pembangunan jalan kereta api dan rencana pengembangan pelabuhan laut di daerah Garongkong. Kondisi rencana pengembangan kawasan Garongkong sebagai kawasan pusat pertumbuhan baru telah dibuat rencana tata ruang yang matang untuk dijadikan sebagai dasar dan pertimbangan dimasa yang akan datang.

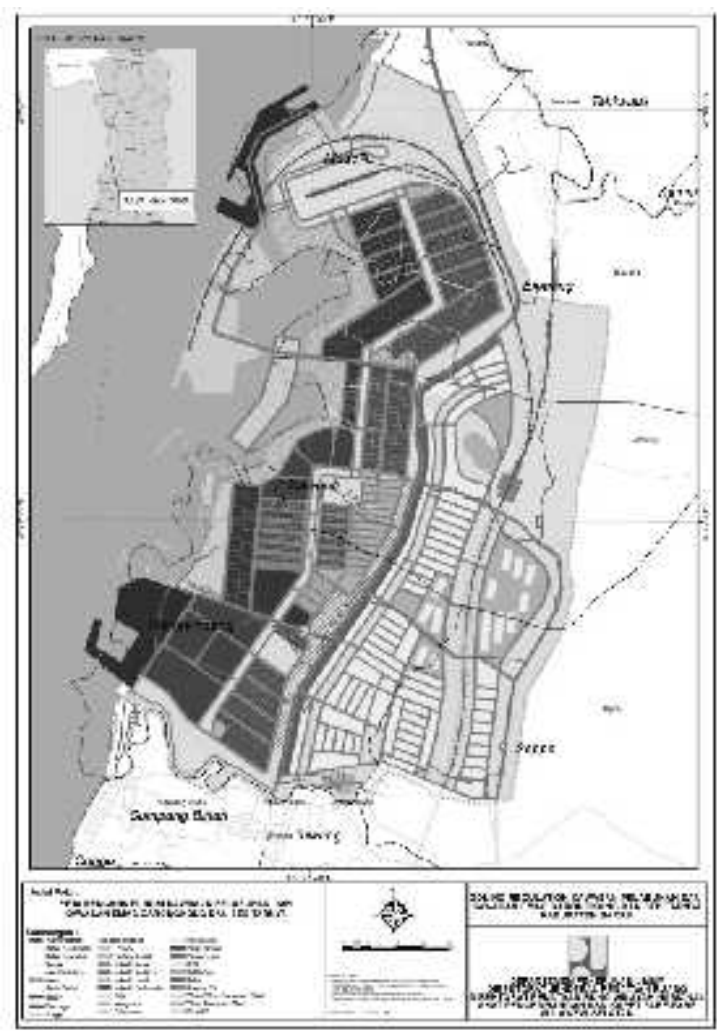

Gambar 2. Rencana zonasi kawasan Garongkong dan sekitarnya

\section{c. Sebaran Titik persinggahan}

Titik persinggahan kendaraan yang merupakan cikal bakal rest area di Kabupaten Barru telah tersebar disepanjang jalur utama. Penelusuran lapangan dari arah Kota Pare Pare kearah Kota Makassar disepanjang jalur poros utama yang membelah kawasan Kabupaten Barru ditemukan sejumlah titik persinggahan. Titk persinggahan kendaraan ini kami sebut sebagai rest area bayangan.

Rest area bayangan merupakan usaha kegiatan ekonomi masyarakat yang dikelola secara mandiri. Bentuk usaha ini dapat dikelompokkan menjadi dua bagian menurut badan usaha pengelolanya, kelompok usaha mandiri dan kelompok pengembangan usaha dengan manajemen yang professional.

Kelompok pengembangan usaha mandiri berbentuk warung makan yang dikelola secara tradisional. Sifat kegiatan ini adalah dengan menyajikan dagangan dan mengharapkan pengunjung datang secara suka rela. Kepasrahan dalam berusaha merupakan dasar penggerak dari kegiatan seperti ini. Kegiatan usaha mandiri terdiri dari gabungan kelompok masyarakat dengan jajanan yang berbeda dan usaha dengan jajanan tunggal. Jajanan tunggal yang dimaksud adalah kegiatan usaha yang dikelola secara mandiri dengan menu tertentu yang dikelola secara total oleh pemilik usaha. Kegiatan usaha gabungan merupakan kegiatan usaha yang dilakukan dengan cara membuat kelompok jajanan makan minum disuatu tempat. Kelompok ini menguasai umumnya satu jenis jajanan

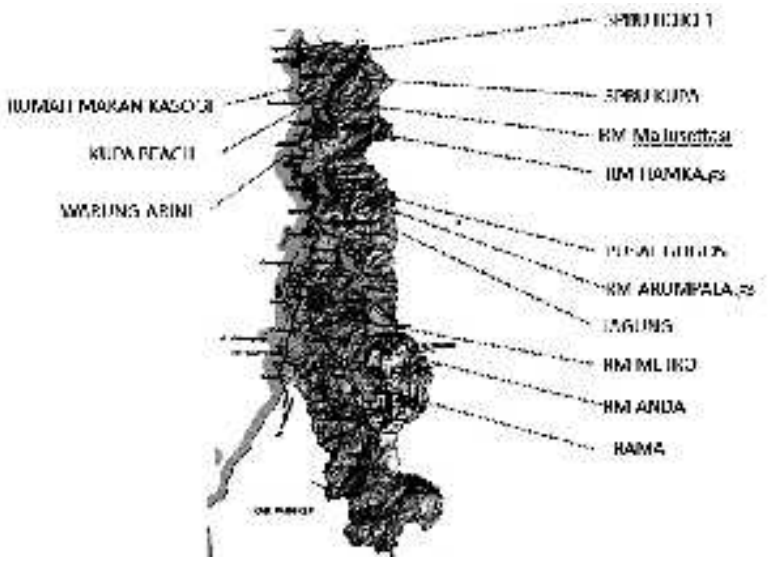

Gambar 3. Titik sebaran rest area bayangan di Kabupaten Barru

Posisi persinggahan kendaraan eksisting yang terjadi di Kabupaten Barru sebagaimana disajikan dalam peta di atas menunjukkan gambaran kepadatan persinggahan ditempat ini. Kepadatan persinggahan ini meskipun dinyatakan secara kualitatif tetapi kuantitas dan frekuensi kegiatan persinggahan yang terjadi secara alami saat ini dapat dilihat secara kasat mata.

Penelusuran persinggahan eksisting yang dilakukan dari arah Kota Pare-Pare menuju Kota Makassar menemukan kegiatan persinggahan yang cukup beragam. Secara berturut yang dari pertama di SPBU Bojo I, Rumah makan Kasogi, SPBU Suppa, Kupa Beach, Rumah Makan Hamka, Warung Arini, Pusat penjualan gogos, Rumah makan arumpala, 
Pusat penjualan jagung, Rumah makan Metro, Rumah Makan Anda, SPBU Rama.

Lokasi sebaran titik tersebut diatas tersebar disepanjang jalan dan menggunakan sisi jalan secara langsung, tidak ada lokasi yang terletak jauh dari pinggir jalan. Jumlah fasilitas persinggahan lebih banyak berada di sisi timur jalan atau jalur poros Pare Pare menuju Kota Makassar. Lokasi fasilitas menurut posisinya terhadap sisi timur barat tepi jalan yang tidak berimbang terlihat adanya kecendrungan mengundang bahaya.

\section{d. Sirkulasi Arus Kendaraan Bergerak dan Proyeksi 10 tahun dan 25 tahun}

Tempat pemilihan lokasi survey dilakukan dengan cara random. Titik survey dipilih di mana pengguna kendaraan di kawasan ini biasaya berhenti. Pengamatan dilakukan secara efektif selama kurun waktu 15 menit. Pemilihan waktu ini di dasarkan atas kemampuan surveyor untuk mendata secara efektif berada dalam rentang waktu tersebut. Pengukuran kepadatan arus sirkulasi kendaraan di Kabupaten Barru perlu dilihat dari dua arah. Karena jumlah kendaraan yang berlalulintas sangat padat. Penagmatan satu arah akan meningkatkan kualitas data untuk mendapat hasil analisis yang berkualitas. Berikut adalah hasil pencatatn jumlah dan jenis kendaraan menurut arus satu arah di Kabupaten Barru.

Tabel.3 Jumlah Pergerakan kendaraan arah utara ke selatan di Kabupaten Barru dalam Rentang waktu 15 menit

\begin{tabular}{|c|c|c|c|c|c|c|c|c|c|}
\hline \multirow[b]{2}{*}{ No } & \multicolumn{2}{|c|}{ Jam } & \multicolumn{6}{|c|}{ Jenis Kendaraan } & \multirow[b]{2}{*}{ Keterangan } \\
\hline & \begin{tabular}{|l|} 
awal \\
\end{tabular} & akhir & 2 roda & 4 roda & Box & bus & truk & trailer & \\
\hline 1 & 7.30 & 7.45 & 120 & 110 & 2 & & 2 & 1 & \\
\hline 2 & 8.00 & 8.15 & 135 & 140 & 5 & & 5 & 3 & \\
\hline 3 & 9.00 & 9.15 & 120 & 110 & 3 & 2 & 4 & 2 & \\
\hline 4 & 10.00 & 10.15 & 85 & 98 & 3 & 2 & 4 & 2 & \\
\hline 5 & 11.00 & 11.15 & 95 & 110 & 2 & & 3 & & \\
\hline 6 & 12.00 & 12.15 & 75 & 95 & 7 & 2 & 16 & 4 & \\
\hline 7 & 13.00 & 13.15 & 61 & 125 & 5 & & 17 & 6 & \\
\hline 8 & 14.00 & 14.15 & 113 & 150 & & 3 & 28 & 4 & \\
\hline 9 & 15.00 & 15.15 & 88 & 118 & 5 & & 7 & 4 & \\
\hline 10 & \begin{tabular}{|l|}
16.00 \\
\end{tabular} & 16.15 & 53 & 66 & 3 & & 9 & 4 & \\
\hline 11 & 17.00 & 17.15 & 42 & 60 & 3 & & 15 & 8 & \\
\hline 12 & 18.00 & 18.15 & 31 & 57 & 7 & 5 & 6 & 7 & \\
\hline 13 & 19.00 & 19.15 & 45 & 56 & 5 & 5 & 5 & 3 & \\
\hline 14 & 20.00 & 20.15 & 30 & 45 & 4 & 4 & 6 & 3 & \\
\hline 15 & 21.00 & 21.15 & 35 & 40 & 3 & 4 & 7 & 4 & \\
\hline & & Total & 1128 & 1380 & 57 & 27 & 134 & 55 & \\
\hline & & \begin{tabular}{|l|} 
Rataan \\
\end{tabular} & 75.2 & 92 & 4.071429 & 3.375 & \begin{tabular}{|l|}
8.933333 \\
\end{tabular} & 3.928571 & \\
\hline
\end{tabular}

Sumber : Hasil Survey

Dalam tabel tersebut diatas dapat dilihat bahwa rata rata kendaraan yang begerak di jalur poros Barru dari arah utara yaitu dari arah Kota Pare Pare ke arah selatan atau arah Kota Makassar ditemukan sejumlah rata-rata 75,2 kendaraan roda dua; 92 unit kendaraan roda empat. 4 unit mobil box; 3,37 unit kendaraan bus; 8, 93 unit truk; dan 3,92 unit kendaraan trailer.

Data dalam tabel mengindikasikan adanya pergerekan kendaraan yang berflutuasi menurut rentang waktu. Waktu kendaraan terpadat ditemukan disekita waktu tengah hari. Jumlah pergerakan kendaraan terjadi penurunan seiring dengan perjalanan waktu menuju malam hari.

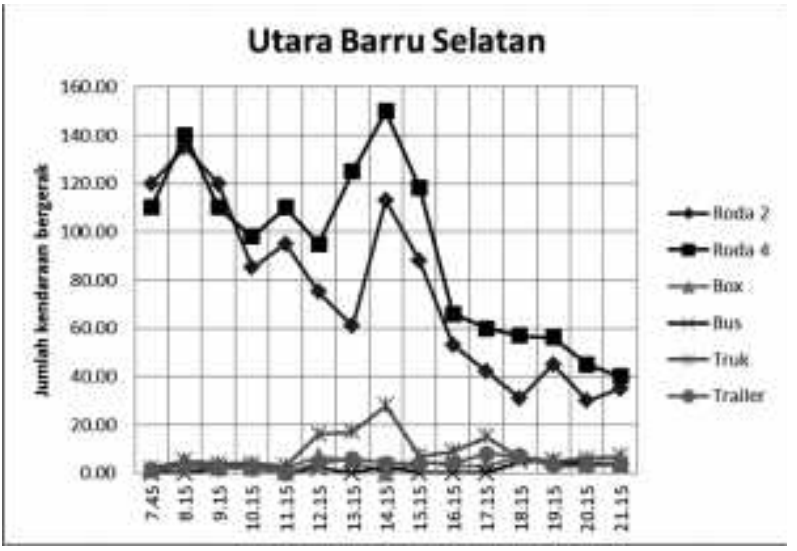

Gambar 4. Grafik pergerakan kendaraan di jalan poros Barru arah utara ke selatan

Tabel. 4 Jumlah Pergerakan kendaraan arah selatan ke utara di Kabupaten Barru dalam Rentang waktu 15 menit

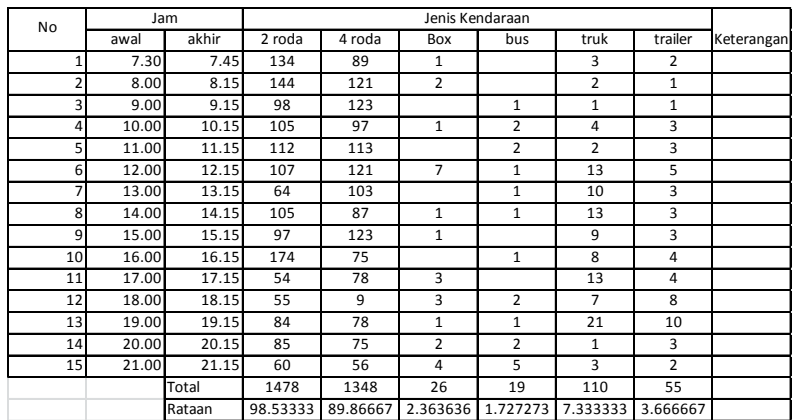

Sumber : Hasil Survey

Tabel di atas menjelaskan bahwa jumlah rata-rata kendaraan roda dua yang bergerak dari arah selatan keutara atau dari arah Kota Makassar ke arah kota Pare-Pare yang melintasi Kabupaten Barru ditemukan sejumlah 98,53 kendaraan roda2 ; 89,86 kendaraan roda empat; 2,363 unit kendaraan box; 1,72 unit kendaraan bus; 7,3 unit kendaraan truk; dan 3,66 unit kendaraan trailer.

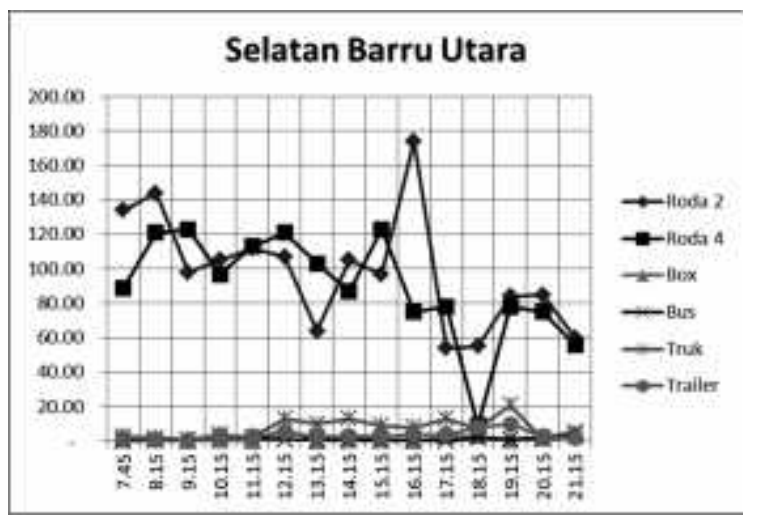

Gambar 5. Grafik pergerakan kendaraan di jalan poros Barru arah selatan ke utara

Data dalam grafik memperlihatkan grafik pergerakan kendaraan menurut waktu. Pergerakan 
kendaraan dari arah yang berlawanan dengan grafik sebelumnya memperlihatkan adanya pergerakan yang berimbang. Dalam grafik terlihat adanya pergerakan relative lebih stabil pada saat perjalanan dari arah selatan ke utara. Pergerakan dari arah sebaliknya memperlihatkan kecenderungan pengurangan jumlah menjelang sore hari.

Berdasarkan data perkembangan jumlah kendaraan yang beroperasi di Provinsi Sulawesi Selatan sebesar $7,525 \%$ maka prediksi jumlah kendaraan yang melintas di Kabupaten Barru dapat diprediksi untuk jangka pendek dan jangka menegah. Jangka pendek diperhitungkan 10 tahun yang akan datang sedangkan jangka menengah diperhitungkan 25 yang akan datang.

Prediksi jumlah LHR kendaraan jangka pendek yang melintas dari arah utara ke arah selatan di Kabupaten Barru adalah:

$\mathrm{P}_{2026}=185\{1+(0,07525 \times 10)\}=324,2125$ unit kendaraan.

Terdiri dari:

$\mathrm{P}_{\text {motor } 2026}=75,2\{1+(0,07525 \times 10)\}=131,788$ unit kendaraan. $(40,6 \%)$

$\mathrm{P}_{\text {smp } 2026}=92\{1+(0,07525 \times 10)\}=161.23$ unit kendaraan. $(49,67 \%)$

$\mathrm{P}_{\mathrm{wv} 2026}=18,2\{1+(0,07525 \times 10)\}=31,895$ unit kendaraan. $(9,8 \%)$

Prediksi LHR kendaraan yang melintas dari arah selatan ke arah utara di Kabupaten Barru adalah:

$P_{2026}=202,4\{1+(0,07525 \times 10)\}=354,706$ unit kendaraan.

Terdiri dari:

$\mathrm{P}_{\text {motor } 2026}=98,53\{1+(0,07525 \times 10)\}=172,673$ unit kendaraan. (48.66\%)

$\mathrm{P}_{\text {smp } 2026}=89,87\{1+(0,07525 \times 10)\}=157.49$ unit kendaraan. $(44,03 \%)$

$\mathrm{P}_{\mathrm{wv}} 2026=14\{1+(0,07525 \times 10)\}=24,535$ unit kendaraan . ( 6,91\%)

Data tersebut memberi gambaran bahwa 10 tahun yang akan datang jumlah kendaraan yang bergerak di Kabupaten Barru adalah sebanyak 678,9 atau dibulatkan sekitar 679 unit setiap 15 menit.

\section{e. Analisa Peluang Perkembangan Ekonomi}

Analisis petumbuhan ekonomi Kabupaten Barru dengan kehadiran rest area di kawasan ini dapat dilihat dari dua sisi, sisi langsung dan tak langsung. Sisi langsung berkaitan dengan terbukanya peluang usaha dan pengembangan usaha. Sisi tak langsung berakibat dari efek pembangunan yang akan menjadi pemicu peningkatan pendapat daerah. Peluang dari sisi tak langsung dapat dikemukakan dari kehadrianpembangunan rest area akan berfungsi sebagai penggerak ekonomi di kawasan ini. Pembangunan rest area sebagai bagian dari kegiatan industry konstruksi akan menjadi pemicu pergerakan ekonomi.

Kegiatan pembangunan fisik rest area di Kabupaten Barru akan menjadi generator penggerak eknomi dalam hal penyerapan tenaga kerja dan perdagangan bahan bangunan yang akan digunakan di proyek tersebut. Peran industry konstruksi sebagai penggerak peningkatan Pendapatan Domestik Bruto (PDB) suatu daerah telah menjadi rumus umum. Kegiatan industry konstruksi seperti pembangunan rest area akan menggerakaan banyak industry lain yang terkait. Industry lain yang menggunakan tenaga kerja akan mendapatkan imbas perbaikan akibat kegiatan ini.

Pembangunan rest area akan menggerakaan industry efek domino dari industry bahan bangunan. Industry beton, industry kramik, industry besi, industry bahan atap dan bahkan industry bahan bangunan alam akan mendapat efek pertumbuhan ekonomi dari kegiatan pembangunan rest area. Peluang pertumbuhan ekonomi baru dapat dilihat dari terbukanya kebutuhan utama dan kebutuhan pelengkap rest area yang akan menjadi arena bisnis bagi pengusaha.

\subsection{Pembahasan dan Arahan Desain}

Alternatif Rencana pembangunan rest area yang memungkinkan adalah Lawallu, Suasana tapak dapat dilihat dalam gambar di bawah. Luas lahan yang tersedia sekitar 4,59 Ha. Hasil dari Perancangan Rest Area Barru di ambil berdasarkan penggambaran konsep MICHI NO EKI yaitu konsep yang menyediakan tempat beristirahat, wisata, layanan seperti tempat makan, serta di lengkapi dengan media untuk mempromosikan produk-produk yang khas dan aktivitas local.

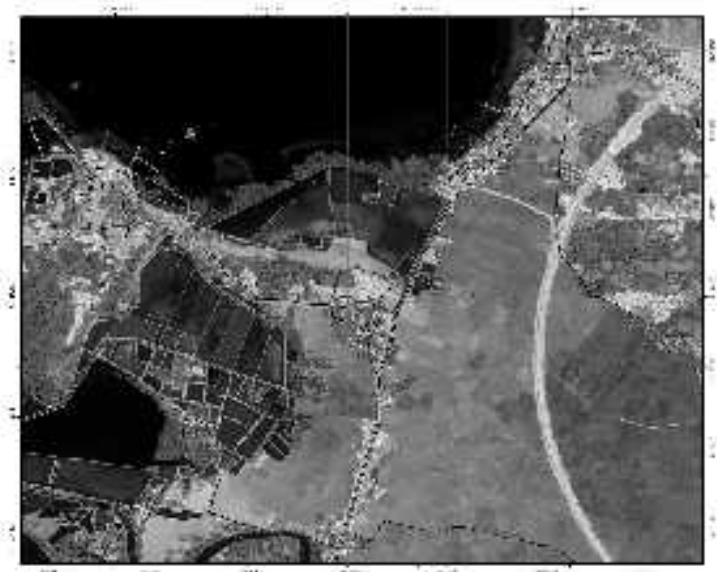

Gambar 6. Lokasi Desa Lawallu

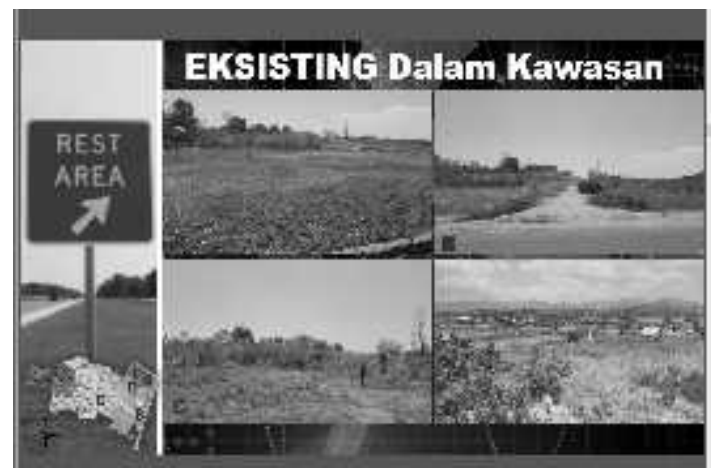

Gambar 7. Eksisting dalam kawasan 


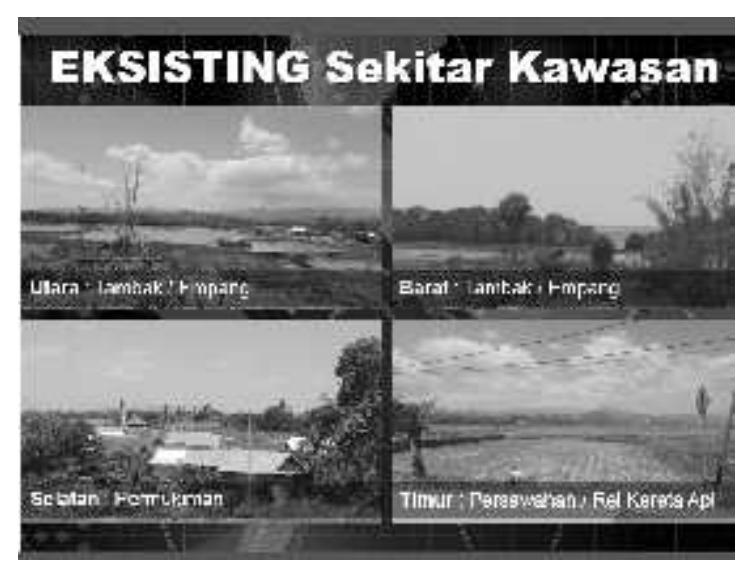

Gambar 8. Eksisting sekitar kawasan

\section{a. Konsep Tata Massa}

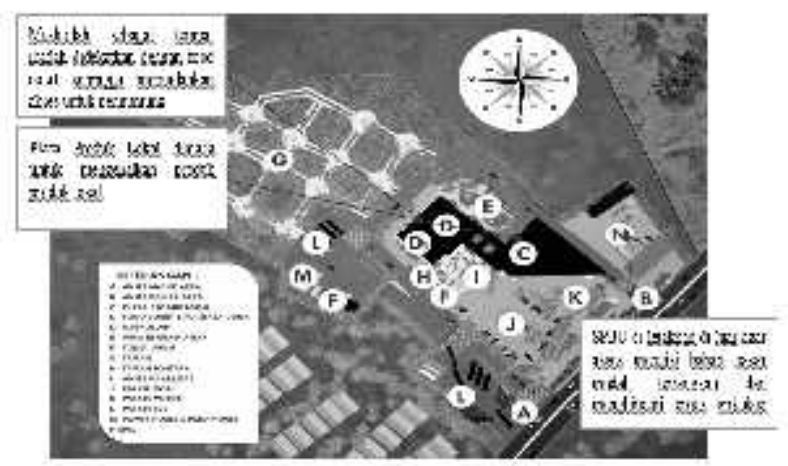

Gambar 9. Konsep Tata Massa

Kegiatan pengembangan kawasan yang dapat dilakukan adalah dengan membuat rencana permukaan kontur baru didaerah yang akan digunakan sebagai pelataran parkir. Kawasan yang akan digunakan sebagai fasilitas peristirahatan akan dikembangkan di atas ketinggian permukaan.

Penggunaan tempat peristirahatan di atas tempat ketinggian akan memberikan nilai positif terhadap kualitas pemulihan tanaga dan kejiwaan. Lahan pembangunan sedapat mungkin melakukan perubahan lingkungan alamiah daerah perbukitan yang menyajikan keindahan pemandangan disekelilingnya merupakan asset peristirahatan yang cukup tinggi. Penambahan unsur buatan diupayakan seminimal mungkin.

\section{b. Konsep Tata Aktifitas}

- Aktifitas Pengunjung : aktifitas yang Banyak dilakukan oleh pengunjung Rest Area seperti berkegiatan di fungsi utama, dan ada pelaku pendukung pada aktifitas di rest area seperti pengelola masing-masing, retail, penjaga keamanan, cleaning service, dsb memilki waktu bekerja dalam aktifitas pengelola.

- Aktifitas Perkantoran : segala aktivitas yang dilakukan oleh semua pengelola Rest Area dan SPBU mulai dari General Manager Hingga Staff. Aktifitas ini tergolong aktifitas pengelola.
- Aktifitas Penunjang : Aktifitas yang dilakukan dengan memfasilitasi pengunjung atau pengelola dari Rest Area.

\section{c. Konsep Tata Sirkulasi}

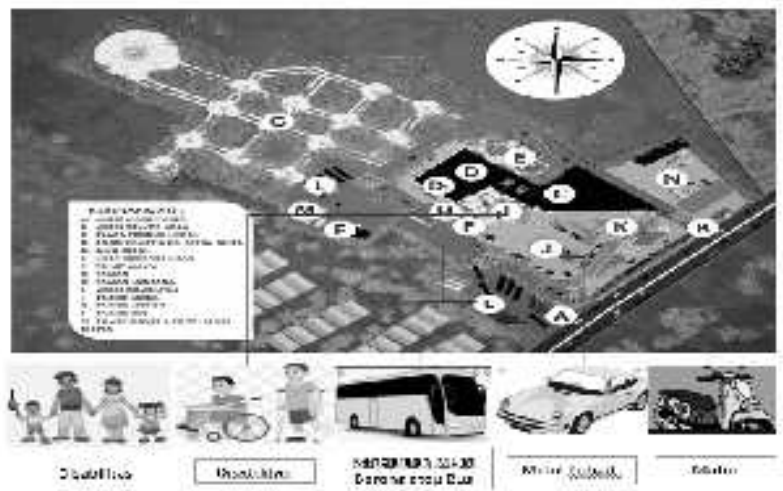

Gambar 10. Konsep Tata Sirkulasi

Setelah ditetapkannya zoneplan dalam tapak maka tahap berikutnya adalah merancang jalan penghubung antar peruntukan tersebut. Hal ini dinamakan sirkulasi dalam tapak. Berdasarkan tipe penggunanya maka sirkulasi dalam tapak dibedakan menjadi tiga jenis,yakni :

- Sirkulasi Manusia

Merupakan pergerakan yang dilakukan manusia sebagai pengguna dan pemakai utama bangunan. Sirkulasi ini dapat berbentuk sederhana hingga kompleks dan rumit.

- Sirkulasi Kendaraan

Merupakan pergerakan kendaraan yang dipakai pengguna dan pemakai bangunan. Dalam perancangan sirkulasi kendaraan, perlu disesuaikan dengan standar dan dimensi kendaraan, jalan dan parkir dengan fungsi tipologi bangunannya. Jenis kendaraan memiliki dimensi yang berbeda yang berdampak juga pada perancangan area pergerakan (manuver) dari kendaraan itu sendiri.

- Sirkulasi Barang

Pada fungsi-fungsi tertentu, sirkulasi didalam tapak justru didominasi oleh pergerakan benda dan barang, misalnya perencanaan dan perancangan pabrik, pelabuhan bongkar muat, atau komplek pergudangan. Pada bangunan umum seperti kantor, rumah sakit atau hotel sirkulasi barang sebaiknya memiliki jalur tersendiri agar kesan yang ditimbulkan tidak merusak pandangan dari pengunjung lainnya.

\section{d. Zona Tapak dan Bangunan}

Perancangan Rest Area Desa Lawallu, Kecamatan Soppeng Riaja Kabupaten Barru memiliki beberapa pembagian ruang. Bagian yang menjadi titik yaitu bangunan Mushollah yang tergabung dengan Food Court dan Plaza Produk Lokal (MICI NO EKI) serta area terbuka hijau. Pembagian zona antara Publik, Privat dan Semi 
Privat terdapat dalam Perancangan Rest Area Kabupaten Barru.

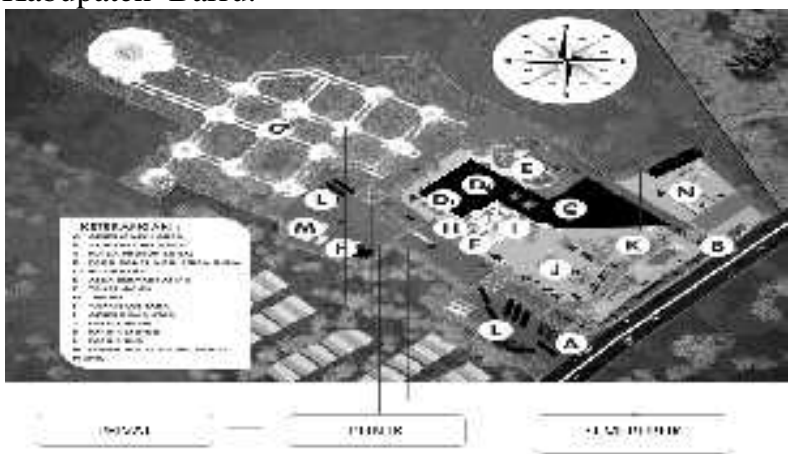

Gambar 11. Zona Bangunan

(Sumber : Hasil Rancangan)

e. Arahan Desain

- Mushollah dan Food Court
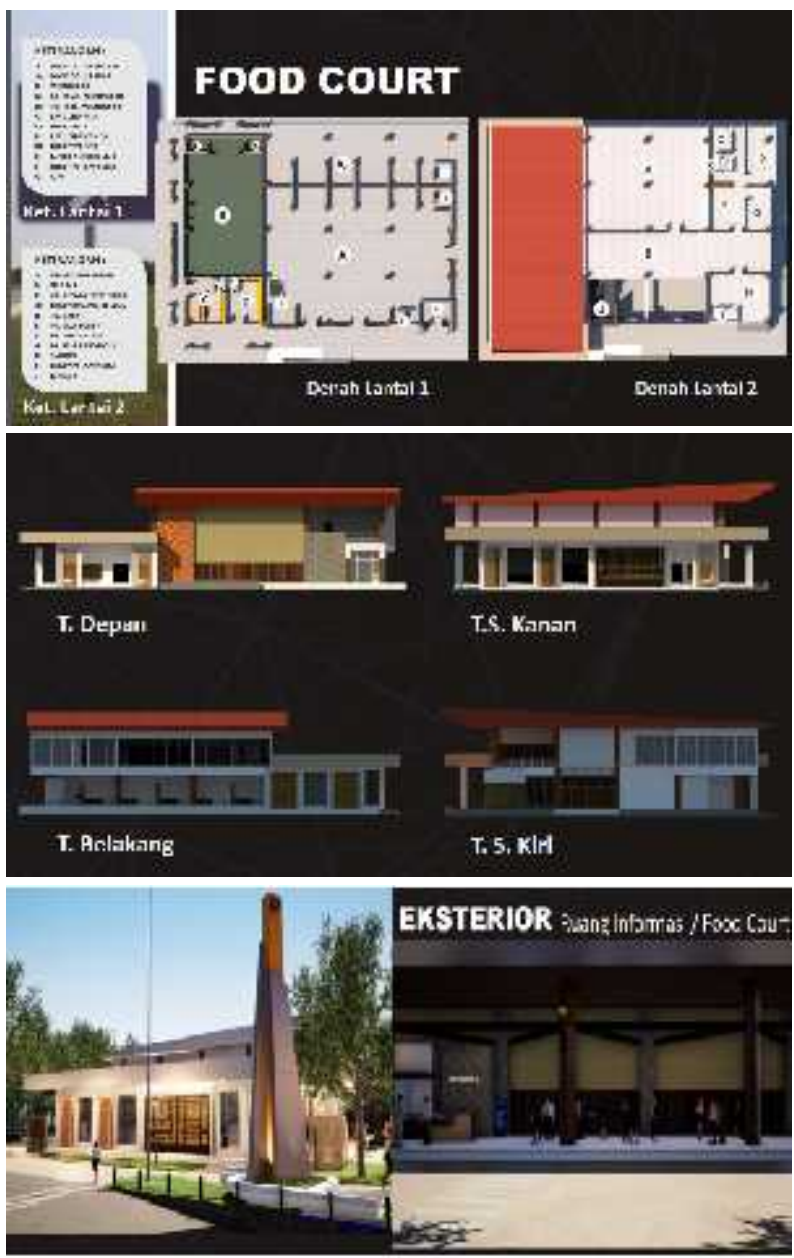

Gambar 12. Denah,Tampak dan 3 Dimensi (Sumber : Hasil Rancangan)

Musholla di letakkan di bagian Barat Daya pada lantai 1, untuk memudahkan pengunjung untuk singgah beribadah, sedangkan di samping mushollah di buatkan Food Court untuk mempermudahkan akses pengunjung untuk menikmati beberapa makanan dan minuman, pada lantai dua di buatkan ruang serbaguna, dimana bisa di tempati untuk acara acara rapat dan lain-lain. Sedangkan di depaan Mushollah terdapat area terbuka hijau untuk memanjakan mata pengunjung

- Plaza Produk Lokal, ATM Center dan Klinik

Plaza Produk Lokal, ATM Center dan Klinik di jadikan satu bangunan,di letakkan di sisi timur, dimana penggabungan bentuk massa bangunan untuk memudahkan pengunjung untuk melihat promosi produk-produk unggul yang khas dan aktivitas local, juga terdapat ATM center dan klinik bagi pengunjung yang membutuhkan fasilitas tersebut.

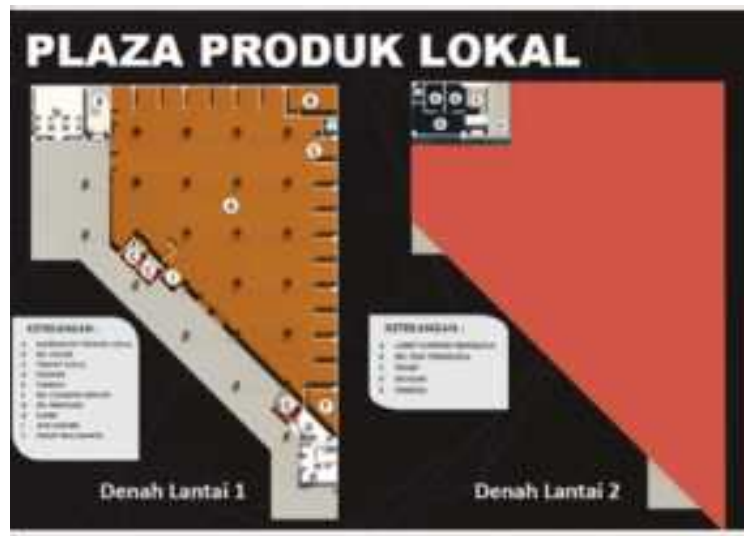

\section{PLAZA PRODUK LOKAL}

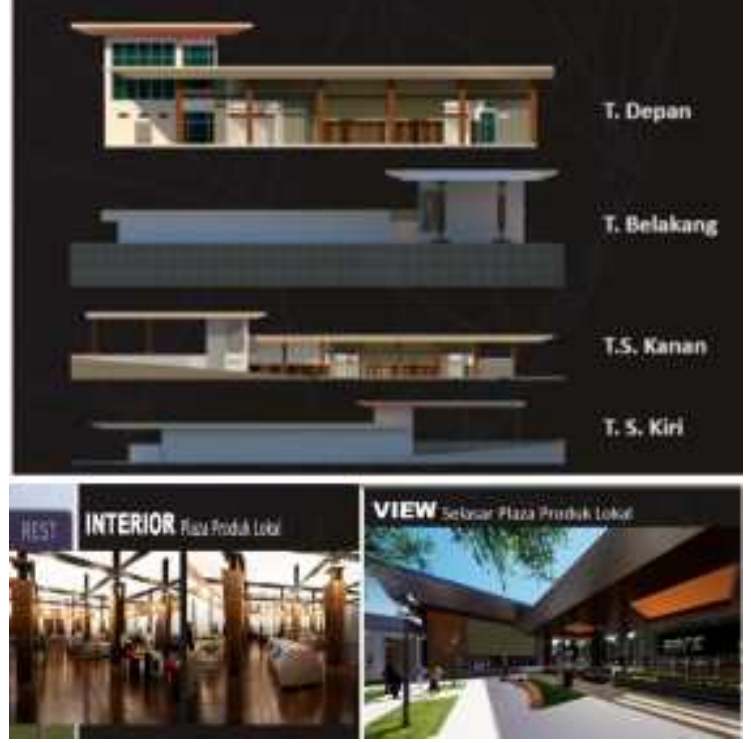

Gambar 13. Denah, Tampak dan 3 Dimensi (Sumber : Hasil Rancangan)

\section{- Power House dan Pump House}

Gedung Power House dan Pump House merupakan area servis berada di luar bangunan utama agar tidak mengganggu aktivitas pengunjung. Gedung ini sendiri terdiri dari ruang mekanikal, ruang pompa air, ruang genset, panel listrik dan lainlain. 


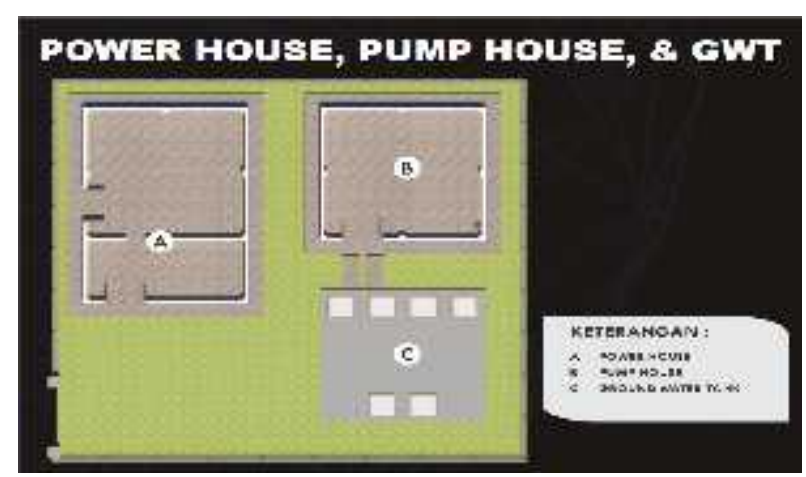

POWER HOUSE, PUMP HOUSE, \& GWT

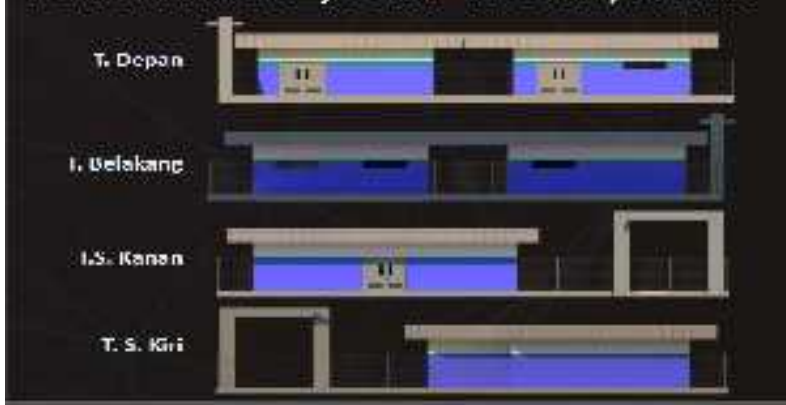

Gambar 14. Denah dan Tampak

(Sumber : Hasil Rancangan)

- SPBU, Office, Tempat cuci mobil dan Bengkel

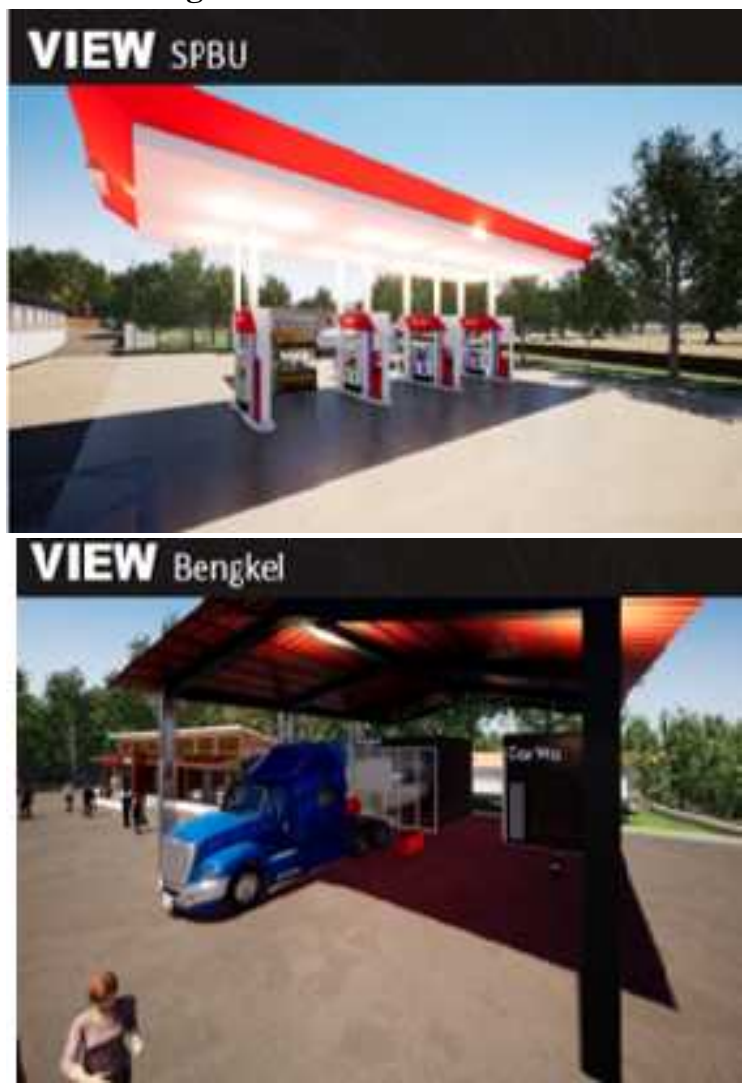

Gambar 15. 3 Dimensi SPBU \& Bengkel

(Sumber : Hasil Rancangan)

SPBU atau tempat pengisian bahan bakar kendaraan di tempatkakan dibagian Timur, SPBU merupakan fasilitas yang sangat penting dan sangat di butuhkan untuk setiap pengendara yang ingin mengisi bahan bakar untuk perjalanan jauh. Serta beberapa fasilitas lain berupa Bengkel dan pencucian mobil.

- Toilet Umum

Toilet Umum diletakkan di bagian depan untuk mempermudah para pengunjung untuk menggunakannya
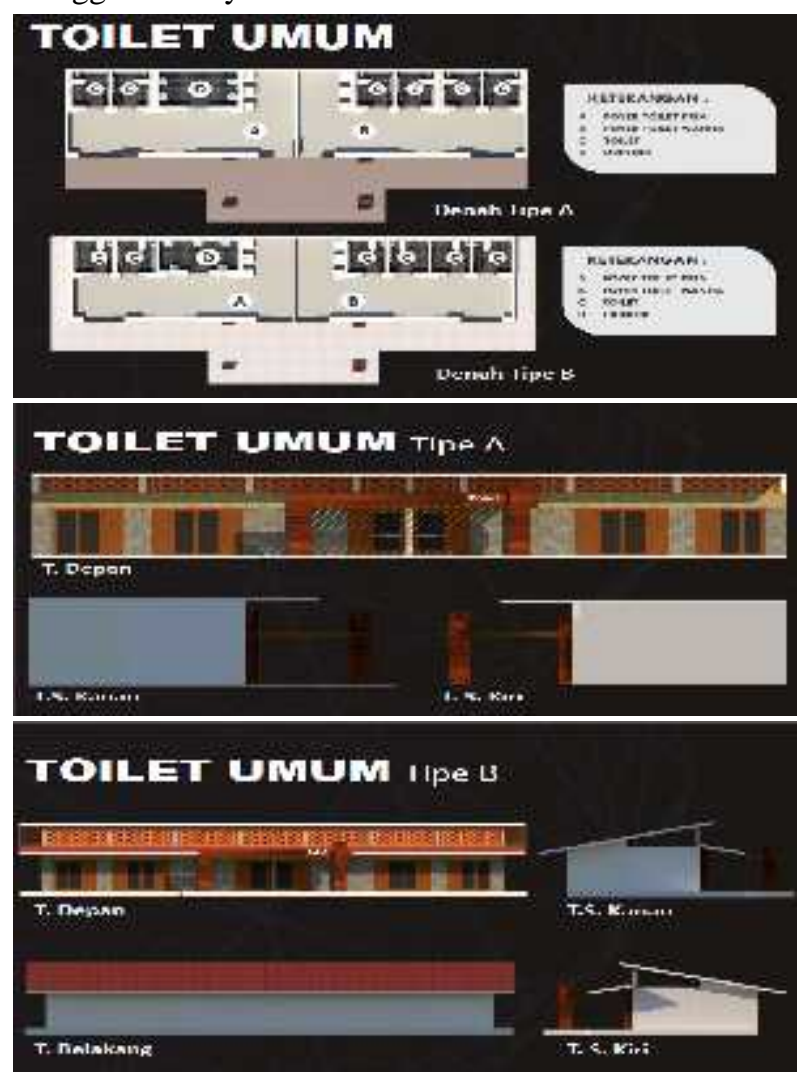

\section{EKSTERIOR Toilct Umum}

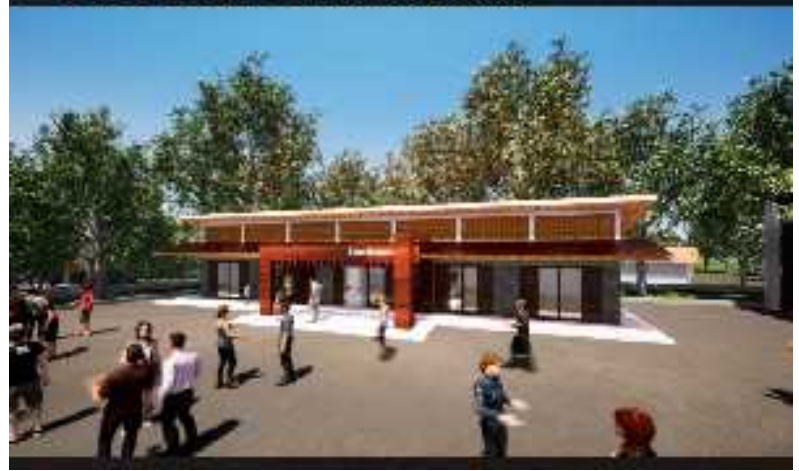

Gambar 16. Denah, Tampak \& Eksterior Toilet (Sumber : Hasil Rancangan)

- RTH, Taman Bermain dan Akses Disabilitas

Ruang Terbuka Hijau (RTH) dan Taman Bermain pada tapak terdapat pada lahan yang tidak terbangun, pada sisi dan depan bangunan terdapat taman-taman yang juga berfungsi sebagai resapan tanaman serta penyejuk suasana bangunan. Akses 
Disabilitas juga sangat di perhitungkan guna memudahkan penyandang disabilitas.
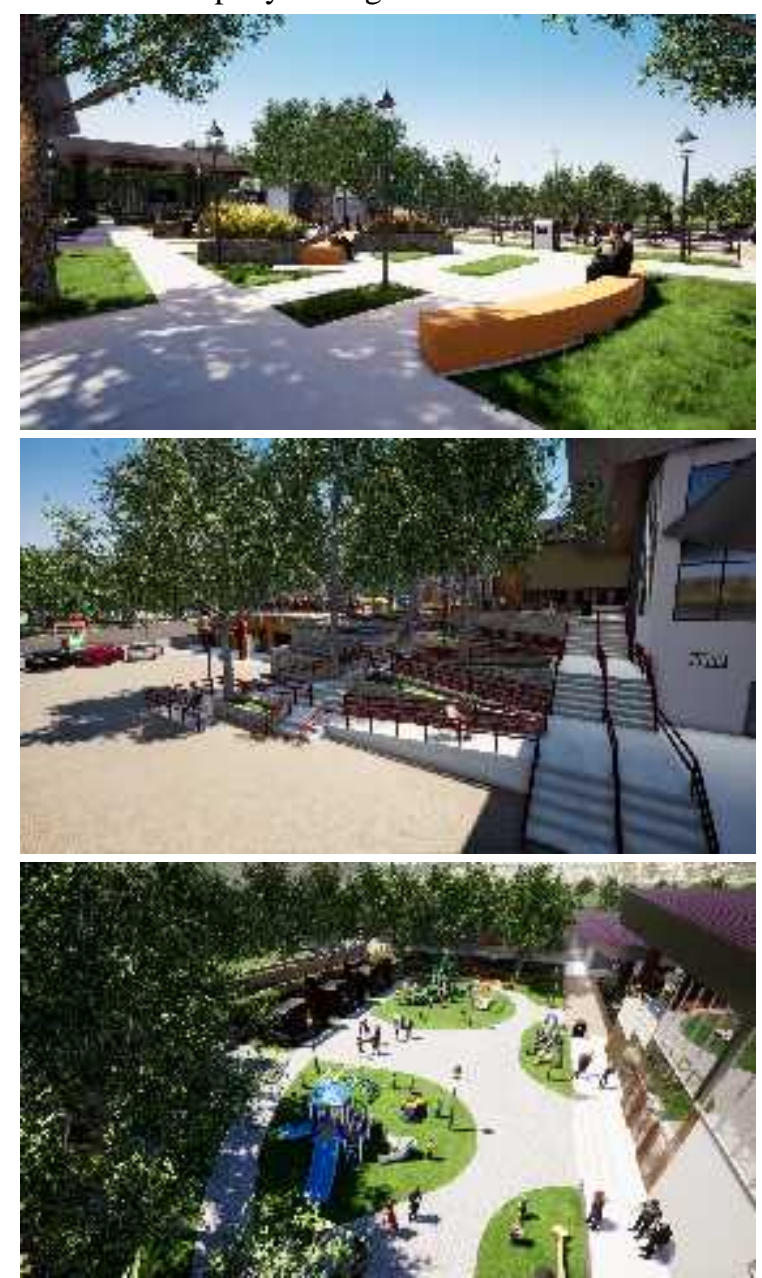

Gambar 17. RTH, Taman Bermain dan

Akses Disabilitas

(Sumber : Hasil Rancangan)

\section{KESIMPULAN \& SARAN}

Rest Area sangat dibutuhkan bagi masyarakat yang sedang dalam perjalanan jauh. Kecelakaan sering terjadi akibat dari pengemudi yang kurang isirahat saat perjalanan jauh, serta kurangnya fasilitas Rest Area. Rest Area sangat penting dengan berbagai fasilitas seperti Musholla, tempat makan/minum, hiburan dan lain-lain.

Perencanaan Rest Area yang baik adalah perancangan yang dapat memfasilitasi kebutuhankebutuhan para pengguna saat istirahat selama dalam perjalanan jauh. Berdasarkan penggambaran konsep MICHI NO EKI yaitu konsep yang menyediakan tempat beristirahat, wisata, layanan seperti tempat makan, serta di lengkapi dengan media untuk mempromosikan produk-produk yang khas dan aktivitas lokal. Dengan ini sangat menguntungkan masyarakat di daerah setempat.

\section{DAFTAR PUSTAKA}

Keputusan Direktur Jendral Perhubungan Darat Nomor 271/HK.105/DRJD/96, Tata Letak Halte terhadap ruang lalu lintas

Keputusan Menteri Perhubungan Nomor KM.65 Tahun 1993, fasilitas Halte

Neufert, Ernst.(1996). Data Arsitek (Jilid 1 - Edisi ke-33), Terjemahan oleh Dr.Ing. SunartoTjahjadi, 7-12.

Neufert, Ernst. (1994). Data Arsitek (Jilid 2 - Edisi ke-2), Terjemahan oleh SjamsuAmril, 14-15.

Undang-Undang Nomor 28 Tahun 2002 Tentang Bangunan Gedung.

Undang-Undang Nomor 26 Tahun 2007 Tentang Penataan Ruang

Peraturan Pemerintah RI No. 14 Tahun 1993 tentang Angkutan Jalan

Permen Pu Nomor 06/Prt/M/2006 Tentang Rencana Tata Bangunan Dan Lingkungan

Permen Pu Nomor 30/Prt/M/2006 Tentang Pedoman Teknis Fasilitas Dan Aksebilitas Pada Bg Dan Lingkungan

Peraturan Menteri Pekerjaan Umum dan Perumahan Rakyat No 10/PRT/M/2018 tentang tempat istirahat dan pelayanan jalan toll (TIP) 